\section{Optimal Rate of Organic Fertilizer during the Flowering Stage for Cannabis Grown in Two Coir-based Substrates}

\author{
Deron Caplan, Mike Dixon, and Youbin Zheng ${ }^{1}$ \\ School of Environmental Sciences, University of Guelph, Guelph, ON N1G \\ 2W1, Canada
}

Additional index words. Cannabis sativa, cannabis growth, floral dry weight, marijuana, THC, THCA, CBGA

\begin{abstract}
In the expanding North American medical cannabis industry, growers lack reliable and systematically investigated information on the horticultural management of their crops, especially with regard to nutrient management and growing substrates. To evaluate organic substrates and their optimal nutrient management, five rates that supplied 57, 113, 170, 226, and $283 \mathrm{mg} N / \mathrm{L}$ of a liquid organic fertilizer $(2.00 \mathrm{~N}-0.87 \mathrm{P}-$ 3.32K) were applied to container-grown plants [Cannabis sativa $\mathrm{L}$. 'WP:Med (Wappa)'] in two coir-based organic substrates. The trial was conducted in a walk-in growth chamber and the two substrates used were ABcann UNIMIX 2-HP (U2-HP) with lower container capacity (CC) and ABcann UNIMIX 2 (U2) with higher CC. U2-HP produced $11 \%$ higher floral dry weight (yield), $13 \%$ higher growth index (GI), $20 \%$ higher $\Delta^{9}-$ tetrahydrocannabinol (THC) concentration, 57\% higher THC yield (per plant), 22\% higher $\Delta^{9}$-tetrahydrocannabidiolic acid (THCA) yield, and $20 \%$ higher cannabigerolic acid (CBGA) yield than U2. Increasing fertilizer rate led to increased growth and yield but also to a dilution of THC, THCA, and CBGA. In U2-HP, to maximize both yield and cannabinoid yield, the optimal organic fertilizer rates were those which supplied 212$261 \mathrm{mg}$ N/L. For U2, the highest applied rate, that supplied $283 \mathrm{mg}$ N/L, maximized yield; although lower rates delivered higher cannabinoid concentrations in dry floral material. The results on these substrates and recommended fertilizer rates can serve as a guide when using other organic fertilizers and substrates; although results may differ with cannabis variety.
\end{abstract}

The North American market for government-regulated cannabis (Cannabis sativa L.) is expanding at an increasing pace. In 2016, spending on medical cannabis was reported at 4.9 billion USD and is projected to exceed 7 billion USD by 2020 in North America (ArcView Market Research, 2017).

Cannabis is an annual herbaceous species which has been widely cultivated and used as a medicinal plant since around $2800 \mathrm{BCE}$ (Russo, 2007). The medicinal value of this species is attributed to a group of secondary metabolites called cannabinoids which are concentrated in the essential oils of unfertilized female flowers (Potter, 2014). Over 100 unique cannabinoids have been identified (Ahmed et al., 2008, 2015; ElSohly and Slade, 2005; Radwan et al., 2015); although $\Delta^{9}$-THC and cannabidiol (CBD) have been most widely studied for their psychoactive

\footnotetext{
Received for publication 15 Aug. 2017. Accepted for publication 24 Sept. 2017.

We thank ABcann Medicinals Inc. for providing funding as well as materials, expertise, and groundlevel support. We also thank Millenniumsoils Coir and EZ-GRO Inc. for providing materials and technical support.

${ }^{1}$ Corresponding author. E-mail: yzheng@ uoguelph.ca.
}

and medicinal properties (Elzinga et al., 2015; Mechoulam et al., 1970; Vemuri and Makriyannis, 2015). In live plants, cannabinoids exist predominantly as carboxylic acids such as $\Delta^{9}$-THCA and cannabidiolic acid (CBDA) (Muntendam et al., 2012). These acids decarboxylate during storage (Ross and ElSohly, 1997; Taschwer and Schmid, 2015) and upon heating (Kimura and Okamoto, 1970) to become neutral cannabinoids such as THC and CBD. Some varieties of cannabis have been selectively bred and cultivated mainly for fiber or seed production; these are characterized by low THC and high CBD concentrations and are generally termed hemp or fiber-type cannabis. Varieties with high THC and low CBD are termed marijuana or drug-type cannabis (van Bakel et al., 2011; Vollner et al., 1986), hereafter referred to as cannabis.

Our communications with Canadian medical cannabis producers, relevant horticulture literature relating to cannabis (Knight et al., 2010; Potter and Duncombe, 2012; Vanhove et al., 2011, 2012) and reviews on global cannabis production (Farag and Kayser, 2015; Leggett, 2006; Potter, 2014) suggest that modern day production occurs primarily in controlled environments using artificial lighting and either soilless growing substrates (Caplan et al., 2017) or solution culture.
Furthermore, most indoor production of cannabis occurs in two growth stages, vegetative and flowering, which are controlled by photoperiod (Potter, 2014). Cannabis production has been and continues to be illegal in much of the world which has limited scientific research on this species, particularly with regard to its production. Growers have access to horticultural guides and online resources but few are based on scientific research. Published information on hemp production allows for some parallels to be drawn; however, hemp is a field-grown crop and has been selectively bred for fiber or seed production rather than for flower and essential oil production (Amaducci et al., 2015). In addition, recent studies have found low gene flow between cannabis and hemp (Hillig and Mahlberg, 2004; van Bakel et al., 2011) making it difficult to relate cultivation techniques between the two crops (Amaducci et al., 2015). The lack of horticultural information on cannabis limits producers and patients seeking to grow or consume consistent, high quality medicine.

Fertilization is one of the most important factors for indoor cannabis production. Overfertilization can lead to salt accumulation in the root zone, whereas under-fertilization can cause nutrient deficiency and lower yields (Bar-Yosef, 1999). The suggested fertilization rate for hemp ranges from 50 to $200 \mathrm{~kg}$ N/ha (Aubin et al., 2015; Ehrensing, 1998; Vera et al., 2004) which is similar to other high-yielding field crops such as wheat (Triticum spp.; Baxter and Scheifele, 2008). It is difficult, however, to base fertilizer rates for cannabis on suggestions for hemp or other crops because of the differences in species and growing conditions (Wright and Niemiera, 1987). Furthermore, it is common for nutrient requirements to vary based on growth stage in flowering plants. The vegetative growth stage in flowering plants is characterized by an exponential growth rate (biomass increase) and often a higher nutrient demand (Raviv and Lieth, 2007). The flowering stage is characterized by a linear growth rate. In this stage, carbohydrates are translocated to reproductive organs such as flowers and seeds and nutrient demand decreases (Raviv and Lieth, 2007). Varying fertilizer requirements by growth stage have been reported in greenhouse-grown crops such as sweet peppers (Capsicum annum L.), for which the highest total plant and fruit yield was achieved by supplying $30 \% \mathrm{~N}$ from $\mathrm{NH}_{4}{ }^{+}-\mathrm{N}$ in the vegetative stage and using only $\mathrm{NO}_{3}{ }^{-}-\mathrm{N}$ in the flowering stage (Xu et al., 2001). A recent evaluation on the effects of organic fertilization during the vegetative stage for cannabis suggests that overfertilization during the vegetative stage may decrease both THC concentration in floral material and floral dry weight (yield; Caplan et al., 2017) on harvest. An optimal fertilizer rate of $389 \mathrm{mg} \mathrm{N} / \mathrm{L}$ was proposed using a liquid organic fertilizer $(4.0 \mathrm{~N}-1.3 \mathrm{P}-1.7 \mathrm{~K})$ in two coir-based organic substrates. To our knowledge, there is no research on floweringstage fertilizer rates for cannabis. 
Appropriate choice of a growing substrate is also important for indoor cannabis production. Substrates vary in physical and chemical properties; therefore, to ensure a suitable root zone environment it is important for fertigation to be tailored to the growing substrate (Zheng, 2016). Substrates with low CC (drier substrates) require more frequent irrigation to keep moisture levels constant, whereas substrates with higher CC (wetter substrates) require less frequent irrigation and may conserve irrigation water (Raviv and Lieth, 2007). Although there is scant research on growing substrates for cannabis, the information we collected from the industry indicates that many North American cannabis producers are using either coir- or peat-based substrates, or inert substrates such as stone wool. Caplan et al. (2017) evaluated two coir-based substrates for vegetative-stage cannabis production. At the end of the vegetative stage, plants were transferred into a growth chamber for the flowering stage under similar conditions to determine if treatment effects carried forward to harvest. The substrates differed in CC by $\approx 11 \%$ but no differences in growth, yield, or cannabinoid content were reported between the two. Vegetative-stage cannabis may grow well in substrates with CCs within a certain range; however, there are no similar evaluations for flowering stage cannabis production.

The objectives of this study were to 1) evaluate two coir-based organic growing substrates for flowering-stage cannabis production in a controlled environment growth chamber, and 2) determine the optimal organic fertilizer rates for these substrates.

\section{Materials and Methods}

Plant culture. Fifteen-day-old rooted cuttings $(\approx 10 \mathrm{~cm}$ high with $\approx 6$ leaves $)$ of $C$. sativa L. 'WP:Med (Wappa)' were transplanted into round peat-based pots $(9.5 \mathrm{~cm}$ diameter $\times 10.2 \mathrm{~cm}$ high; Jiffy Products N.B. Ltd., Shippagan, Canada) filled with ABcann UNIMIX 1-HP growing substrate (ABcann Medicinals Inc., Napanee, Canada) with one plant per pot. Pots were placed in a walk-in growth chamber $\left(15 \mathrm{~m}^{2}\right)$ at a density of 97 plants $/ \mathrm{m}^{2}$.

Table 1. Physical properties of growing substrates ABcann UNIMIX 2-HP (U2-HP) and ABcann UNIMIX 2 (U2).

\begin{tabular}{|c|c|c|c|c|}
\hline & Total porosity ${ }^{z}$ & $\mathrm{CC}^{\mathrm{z}}$ & Air space ${ }^{z}$ & \\
\hline Growing substrate & & $(\%)$ & & Bulk density $\left(\mathrm{g} \cdot \mathrm{cm}^{-3}\right)$ \\
\hline U2-HP & $83 \pm 0.5$ & $49 \pm 0.4$ & $34 \pm 0.4$ & $0.10 \pm 0.001$ \\
\hline $\mathrm{U} 2$ & $91 \pm 0.9$ & $55 \pm 2.2$ & $35 \pm 1.3$ & $0.09 \pm 0.001$ \\
\hline
\end{tabular}

${ }^{\mathrm{z}}$ Data are means $\pm \operatorname{SEM}(n=3) . \mathrm{CC}=$ container capacity.
The chamber air temperature was maintained at $24 / 23{ }^{\circ} \mathrm{C}\left(\mathrm{SD} \pm 0.04 / 1.0{ }^{\circ} \mathrm{C}\right)$ and relative humidity $(\mathrm{RH})$ was $76 / 76 \%(\mathrm{SD} \pm 3.8 /$ $3.9 \%$ ) during the light/dark period throughout the vegetative stage. Carbon dioxide $\left(\mathrm{CO}_{2}\right)$ concentration was maintained at 545 ppm (SD $\pm 45 \mathrm{ppm})$ from 1 to $4 \mathrm{~d}$ after transplant (DAT), $570 \mathrm{ppm}(\mathrm{SD} \pm 18 \mathrm{ppm})$ from 5 to $10 \mathrm{DAT}$ and $613 \mathrm{ppm}(\mathrm{SD} \pm 18 \mathrm{ppm})$ from days 11 to 19 DAT during the light period and $529 \mathrm{ppm}(\mathrm{SD} \pm 18 \mathrm{ppm})$ during the entire dark period. Using dimmable fluorescent lighting (Philips Lighting, Markham, Canada) with an 18-h photoperiod, the photosynthetically active radiation $(P A R)$ at the top of the canopy was maintained at $100 \mu \mathrm{mol} \cdot \mathrm{m}^{-2} \cdot \mathrm{s}^{-1}$ ( $\mathrm{SD} \pm 1 \mu \mathrm{mol} \cdot \mathrm{m}^{-2} \cdot \mathrm{s}^{-1}$ ) from 1 to $4 \mathrm{DAT}, 199$ $\mu \mathrm{mol} \cdot \mathrm{m}^{-2} \cdot \mathrm{s}^{-1}\left(\mathrm{SD} \pm 6 \mu \mathrm{mol} \cdot \mathrm{m}^{-2} \cdot \mathrm{s}^{-1}\right)$ from 5 to 7 DAT, $300 \mu \mathrm{mol} \cdot \mathrm{m}^{-2} \cdot \mathrm{s}^{-1}\left(\mathrm{sD} \pm 2 \mu \mathrm{mol} \cdot \mathrm{m}^{-2} \cdot \mathrm{s}^{-1}\right)$ from 8 to $10 \mathrm{DAT}$, and $337 \mu \mathrm{mol} \cdot \mathrm{m}^{-2} \cdot \mathrm{s}^{-1}$ (SD \pm $49 \mu \mathrm{mol} \cdot \mathrm{m}^{-2} \cdot \mathrm{s}^{-1}$ ) from 11 to $19 \mathrm{DAT}$.

Beginning 3 DAT, plants were handfertigated, as per Caplan et al. (2017), using Nutri Plus Organic Grow liquid organic fertilizer (4.0N-1.3P-1.7K; EZ-GRO Inc., Kingston, ON, Canada) at a rate that supplied $389 \mathrm{mg} \mathrm{N} / \mathrm{L}$ amended with $1 \mathrm{~mL} \cdot \mathrm{L}^{-1}$ of calcium-magnesium supplement $(0.0 \mathrm{~N}-$ $0.0 \mathrm{P}-0.0 \mathrm{~K}-3.0 \mathrm{Ca}-1.6 \mathrm{Mg}$; EZ-GRO Inc.), and with a $20 \%$ leaching fraction. Other nutrient element concentrations of Nutri Plus Organic Grow were (in $\mathrm{mg} \cdot \mathrm{L}^{-1}$ ): $14.5 \mathrm{Zn}$, $12.0 \mathrm{~B}, 2.6 \mathrm{Mo}, 2.1 \mathrm{Cu}$, and 8.5 Fe. Irrigation was administered when mean substrate moisture was $\approx 30 \%$, measured using a WET-2 soil moisture sensor (Delta-T Devices Ltd., Cambridge, UK).

Treatments. At 19 DAT, 60 plants with similar height and canopy size were selected and transferred into a larger walk-in growth chamber $\left(130 \mathrm{~m}^{2}\right)$ for the flowering stage. This was considered the first day of the flowering stage (DFS). Four additional plants were harvested at this stage to measure initial growth attributes. Plants were up-potted into 6 L blow-molded black pots $(220 \mathrm{~mm}$ diameter $\times 220 \mathrm{~mm}$ height) filled with one of two growing substrates, ABcann UNIMIX 2-HP (U2-HP) or ABcann UNIMIX 2 (U2) (physical and chemical properties presented in Tables 1 and 2, respectively; ABcann Medicinals Inc.). The substrates were coir-based organic substrates with two distinct CCs: U2-HP with lower CC and better drainage than U2. Coir weed control disks were used on top of the growing substrate to prevent algae growth.

The experiment was a completely randomized design with two factors: five fertilizer rates and two substrate types, with six replicates for each factor combination. Each potted plant was an experimental unit. Plants were fertilized at one of five rates that supplied 57, 113, 170, 226, and $283 \mathrm{mg} \mathrm{N} / \mathrm{L}$ using Nutri Plus Organic Bloom $(2.00 \mathrm{~N}-$ 0.87P-3.32K; EZ-GRO Inc.), diluted with RO water. Other nutrient element concentrations in Nutri Plus Organic Bloom were (in $\mathrm{mg} \cdot \mathrm{L}^{-1}$ ) $100 \mathrm{Mg}, 10.0 \mathrm{Zn}, 12.8 \mathrm{~B}, 0.1 \mathrm{Mo}$, $2.3 \mathrm{Cu}$, and $6.8 \mathrm{Fe}$. All fertigation solutions were amended with $1 \mathrm{~mL} \cdot \mathrm{L}^{-1}$ of calciummagnesium supplement $\quad(3.0 \mathrm{Ca}-1.6 \mathrm{Mg}$; EZ-GRO Inc.) and with Organa ADD micronutrient supplement, at a rate that supplied $22.9 \mathrm{mg} \mathrm{N} / \mathrm{L}(2.0 \mathrm{~N}-0.0 \mathrm{P}-0.0 \mathrm{~K}$; EZ-GRO Inc.). Other nutrient element concentrations in Organa ADD were (in mg. $\mathrm{L}^{-1}$ ) $100.0 \mathrm{Ca}$, 29,851 Zn, 4892 Mn, 1239 B, 12.7 Mo, 2419 $\mathrm{Cu}$, and $2917 \mathrm{Fe}$. Fertilizer rates were selected based on recommendations for vegetative-stage organic fertilizer rates from Caplan et al. (2017) and previous studies on organic fertigation of greenhouse-grown tomatoes (Solanum lycopersicum L.; Surrage et al., 2010; Zhai et al., 2009).

Plants were spaced on growing tables at a density of 5.3 plants $/ \mathrm{m}^{2}$. PAR was maintained at $581 \mu \mathrm{mol} \cdot \mathrm{m}^{-2} \cdot \mathrm{s}^{-1}\left(\mathrm{SD} \pm 93 \mu \mathrm{mol} \cdot \mathrm{m}^{-2} \cdot \mathrm{s}^{-1}\right)$ throughout the flowering stage under MASTER GreenPower Plus 1000W high pressure sodium lamps (Philips Lighting) with a 12-h photoperiod. Growth chamber air temperature was maintained at $22 / 21{ }^{\circ} \mathrm{C}(\mathrm{SD} \pm 0.8 / 0.5$ ${ }^{\circ} \mathrm{C}$ ) from 1 to $6 \mathrm{DFS}, 20 / 20{ }^{\circ} \mathrm{C}(\mathrm{SD} \pm 0.5 / 0.8$ $\left.{ }^{\circ} \mathrm{C}\right)$ from 7 to $9 \mathrm{DFS}$ and $18 / 17{ }^{\circ} \mathrm{C}(\mathrm{SD} \pm 0.7 /$ $1.0^{\circ} \mathrm{C}$ ) from 10 to 53 DFS during light/dark periods. RH was maintained at $70 / 76 \%$ (SD \pm $2.9 / 2.3 \%$ ) from 1 to $6 \mathrm{DFS}, 64 / 66 \%(\mathrm{SD} \pm 2.5 /$ $2.7 \%$ ) from 7 to 43 DFS, and $56 / 62 \%$ (SD \pm $2.6 / 1.5 \%$ ) from 44 to 53 DFS. Chamber $\mathrm{CO}_{2}$ was maintained at 594/659 ppm ( $\mathrm{SD} \pm 56 / 42$ $\mathrm{ppm}$ ) from 7 to 9 DFS, 673/705 ppm ( $\mathrm{sD} \pm 83$ / $44 \mathrm{ppm}$ ) from 7 to 9 DFS, and 781/838 ppm ( $\mathrm{SD} \pm 83 / 78 \mathrm{ppm}$ ) from 44 to 53 DFS during light/dark periods.

During the first 11 DFS, plants were handfertigated at a rate that supplied $389 \mathrm{mg} \mathrm{N} / \mathrm{L}$ of Nutri Plus Organic Grow and from then on, with the corresponding nutrient solution of Nutri Plus Organic Bloom (including calcium-magnesium and micronutrient supplements) whenever the mean substrate moisture content reached $\approx 30 \%$. Between

Table 2. EC, $\mathrm{pH}$, and nutrient content measured using the saturated media extract procedure (Warncke, 1986) for growing substrates ABcann UNIMIX 2-HP (U2-HP) and ABcann UNIMIX 2 (U2).

\begin{tabular}{|c|c|c|c|c|c|c|c|c|c|c|c|c|c|c|c|c|}
\hline & & & Nitrate $\mathrm{N}$ & $\mathrm{P}$ & $\mathrm{K}$ & $\mathrm{Ca}$ & $\mathrm{Mg}$ & $\mathrm{SO}_{4}{ }^{2-}$ & $\mathrm{Na}$ & $\mathrm{Cl}^{-}$ & $\mathrm{Zn}$ & $\mathrm{Mn}$ & $\mathrm{Cu}$ & $\mathrm{Fe}$ & $\mathrm{B}$ & Mo \\
\hline Growing substrate & $\mathrm{EC}^{\mathrm{z}}\left(\mathrm{mS} \cdot \mathrm{cm}^{-1}\right)$ & $\mathrm{pH}^{\mathrm{z}}$ & \multicolumn{14}{|c|}{$\left(\mathrm{mg} \cdot \mathrm{L}^{-1}\right)$} \\
\hline U2-HP & $2.2 \pm 0.02$ & $6.2 \pm 0.03$ & 5 & 11.8 & 423 & $<1$ & 4.0 & 34.0 & 118.9 & 534 & $<0.01$ & 0.02 & $<0.01$ & 0.2 & 0.09 & 0.01 \\
\hline $\mathrm{U} 2$ & $1.9 \pm 0.04$ & $6.4 \pm 0.02$ & 5 & 9.8 & 353 & $<1$ & 3.2 & 37.0 & 109.4 & 488 & $<0.01$ & 0.02 & $<0.01$ & 0.7 & 0.12 & $<0.01$ \\
\hline
\end{tabular}

${ }^{\mathrm{z}}$ Data are means $\pm \operatorname{SEM}(n=3) . \mathrm{EC}=$ electrical conductivity; $\mathrm{N}=$ nitrogen; $\mathrm{P}=$ phosphorus; $\mathrm{K}=$ potassium; $\mathrm{Ca}=\mathrm{calcium} ; \mathrm{Mg}=\mathrm{magnesium} ; \mathrm{SO}{ }_{4}{ }^{--}=\mathrm{sulfate} ; \mathrm{Na}=$ sodium; $\mathrm{Cl}^{-}=$chloride $\mathrm{Zn}=$ zinc $\mathrm{Mn}=$ manganese; $\mathrm{Cu}=$ copper; $\mathrm{Fe}=$ iron; $\mathrm{B}=$ boron; $\mathrm{Mo}=$ molybdenum. 
days 45 and 53 in the flowering stage, no fertilizer was applied and the substrates were flushed, as per current industry practice, with RO water when mean substrate moisture content reached $\approx 30 \%$. Fertigation solution $\mathrm{pH}$ was adjusted to maintain substrate $\mathrm{pH}$ between 5.5 and 6.3 , measured using the pour-through method (Wright, 1986) during both vegetative and flowering stages.

Substrate electrical conductivity (EC) and $\mathrm{pH}$ measurement. Substrate $\mathrm{pH}$ and EC during the flowering stage were determined weekly using pour-through method. Pour-through solutions were measured using a HI991300 portable $\mathrm{pH} / \mathrm{EC} / \mathrm{TDS} /$ Temperature Meter (Hanna Instruments, Woonsocket, RI).

Growth and yield measurements. During the flowering stage, branch number, canopy area, and plant height were measured every $\approx 7 \mathrm{~d}$ on five randomly selected plants from each treatment. Repeated measurements were made on the same plants throughout the vegetative stage. During the flowering stage, branch number, canopy area, and plant height were measured on all plants at 15, 27, and 53 DFS. Canopy area for each plant was calculated using two perpendicular length measurements at the widest part of the canopy using plant tags as reference points for repeated measurements. Growth index for each plant was calculated as height $(\mathrm{cm}) \times$ length $(\mathrm{cm}) \times$ width $(\mathrm{cm}) \times 300^{-1}$ (Ruter, 1992). At 34 DFS, leaf greenness was measured as chlorophyll content index (CCI), using a CCM-200 chlorophyll content meter (Opti-Sciences Inc., Hudson, NH) from the center of the most recent fully expanded leaf. Plants were harvested at 53 DFS when floral resin on most plants had $\approx 50 \%$ amber coloration. Stems were cut at substrate level; above-ground fresh weight was measured; large leaves were removed from stems and plants were hung to dry at $18{ }^{\circ} \mathrm{C}\left(\mathrm{SD} \pm 0.1^{\circ} \mathrm{C}\right)$ and $49 \% \mathrm{RH}(\mathrm{SD} \pm 4.4 \%)$ for $6 \mathrm{~d}$ then cured at $18{ }^{\circ} \mathrm{C}\left(\mathrm{SD} \pm 0.5{ }^{\circ} \mathrm{C}\right)$ and $58 \% \mathrm{RH}(\mathrm{SD} \pm 3.5 \%)$ for $11 \mathrm{~d}$. Floral material was then cut from stems and leaves were trimmed using a Twister T4 mechanical trimming machine (Keirton Inc., Surrey, BC, Canada) before floral dry weight (yield) measurement.

Floral cannabinoid analysis. The dried and cured floral material was stored in dark and cool conditions according to United Nations Office on Drugs and Crime (2009) before being analyzed by an independent laboratory (RPC Science and Engineering, Fredericton, NB, Canada). Analysis of the neutral cannabinoids $\triangle 9$-THC, CBD, cannabinol $(\mathrm{CBN})$, cannabichromene (CBC), and cannabigerol (CBG) as well as acid forms, $\triangle 9$-THCA, CBDA, and cannabigerolic acid (CBGA) were conducted by highperformance liquid chromatography as described in section 5.4 .8 of United Nations Office on Drugs and Crime (2009).

Statistical analysis. Data were analyzed using JMP Statistical Discovery Version 13.0 (SAS Institute Inc., Cary, NC) at a Type 1 error rate of $\leq 0.05$. Full-factorial analysis of variance with repeated measures was used to determine the effects of substrate, fertilizer and their interaction on substrate EC, $\mathrm{pH}$, plant height, GI, leaf number, and branch number over time. Differences among means were tested using Tukey's multiple means comparison test. Pearson correlation coefficients were calculated to compare cannabinoid concentrations with yield and CCI with GI index and yield. Orthogonal partition and regression analysis (Bowley, 1999) was used to relate substrate $\mathrm{EC}, \mathrm{pH}$, plant growth, yield, and cannabinoid yield/concentrations with fertilizer rate. If the partitioning variance analysis indicated a significant treatment effect, then the treatment effects were partitioned into one or more regression effects followed by an estimation of regression parameters for the best-fit regression. If there was no significant treatment effect, then data were presented as the average of all the treatments (pooled). If cannabinoid concentrations were below the detection limit $(<0.05 \%)$, the values were excluded from the analysis. The residuals of the above analyses were tested for normality and equality of variance using The Shapiro-Wilk test and Bartlett's test, respectively.

\section{Results}

\section{Growth}

During both the 19-d vegetative stage and the 53-d flowering stage, plants grew normally and without any symptoms of nutrient disorder. Pistillate flowers were visible around 12 DFS in all treatments. During the flowering stage (from 0 to 53 DFS), the average aboveground fresh weight increased from 7.1 to 296 $\mathrm{g} /$ plant, branch number increased from 4.5 to 11 branches/plant, and GI increased from 29 to 462 combined across treatments.

Four plants were removed during the trial because of root rot, three in U2 (two at the rate that supplied $57 \mathrm{mg} \mathrm{N} / \mathrm{L}$ and one at the rate that supplied $113 \mathrm{mg} \mathrm{N} / \mathrm{L}$ ), and one in U2-HP (at the rate that supplied $57 \mathrm{mg} \mathrm{N} / \mathrm{L}$ ). In these cases, both younger and older leaves began to show interveinal purpling, leading to chlorosis and necrosis. There was also visible leaf purpling in treatments of $\mathrm{U} 2$, at the rates that supplied 223 and $286 \mathrm{mg} \mathrm{N} / \mathrm{L}$; most of these plants had entirely purple leaves from 32 DFS until harvest.

Generally, plants with higher fertilizer rates had greener leaves. At 34 DFS, there was a positive linear relationship between fertilizer rate and CCI measurements taken from the center of the newest fully expanded leaf (Fig. 1; pooled from both substrates), and there was no difference in CCI between substrate treatments. There was also a positive correlation between CCI and floral dry weight $(r=0.64, P<0.0001)$ and GI at $53 \mathrm{DFS}(r=$ $0.39, P=0.0184)$. Taking CCI measurements became difficult after 34 DFS when trichomes were abundant on the proximal region of leaves which interfered with the readings. There were signs of foliar senescence beginning around week 6 of flowering when older leaves became chlorotic and ultimately necrotic before harvest. These signs of senescence are typical for cannabis.

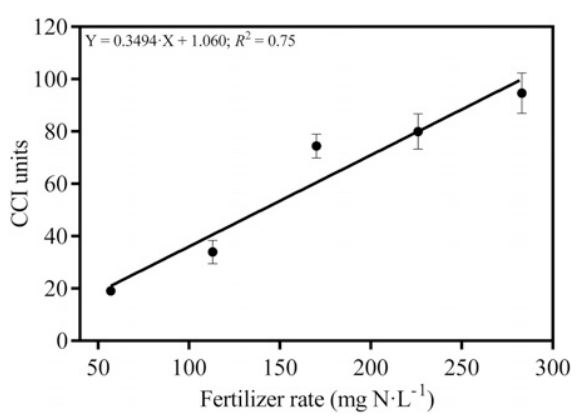

Fig. 1. Response of leaf 'greenness' [chlorophyll content index (CCI) readings] measured on the newest fully expanded leaf to organic fertilizer rate [indicated by nitrogen $(\mathrm{N})$ concentration] at day 34 of the flowering stage. Data were pooled from both substrates. Values are means \pm SEM $(n=8)$ and line is the best-fit regression relationships at $P<0.05$.

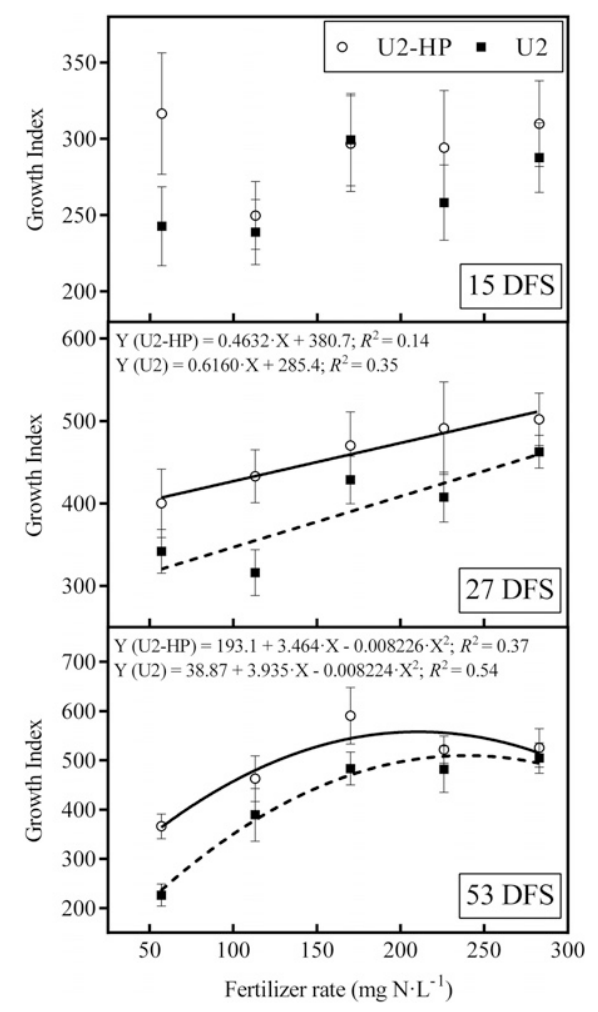

Fig. 2. Response of cannabis growth index to organic fertilizer rate [indicated by nitrogen (N) concentration] in two growing substrates (U2-HP and U2) measured on different days during the flowering stage (DFS). Values are means $\pm \operatorname{SEM}(n=5$ for U2-HP at the rate that supplied $170 \mathrm{mg} \mathrm{N} / \mathrm{L}$ on day 53; for U2 at the rate that supplied $57 \mathrm{mg} \mathrm{N} / \mathrm{L}$ on day 15 and at the rate that supplied $113 \mathrm{mg} \mathrm{N} / \mathrm{L}$ on day 53; $n=4$ for $\mathrm{U} 2$ at the rate that supplied $57 \mathrm{mg} \mathrm{N} / \mathrm{L}$ on day 27 and 53 and $n=6$ for all other means) and lines are the best fit regression relationships at $P<0.05$.

Growth index did not show any treatment effect at 15 DFS, but increased linearly with increasing fertilizer rate at 27 DFS and exhibited a quadratic response at 53 DFS (Fig. 2) for both substrates. At the final 
measurement (53 DFS), the interpolated maximum GI (558) for U2-HP was achieved at a rate supplying $211 \mathrm{mg} \mathrm{N} / \mathrm{L}$, and for $\mathrm{U} 2$ the interpolated maximum (510) was achieved at a rate supplying $239 \mathrm{mg} \mathrm{N} / \mathrm{L}$. Averaged across all fertilizer rates, plants grown in U2-HP had a $13 \%$ higher final GI than in $\mathrm{U} 2(F=9.6, P<0.01)$. No interactive effect was detected between substrate and fertilizer rate on GI.

Branch number did not differ among fertilizer rates or between substrate treatments, and there was no interactive effect of these treatments on branch number. Pooled across all treatments, branch number was 11 $\pm 0.1( \pm$ SEM $)$ at 53 DFS.

\section{Yield}

In both substrates, yield increased with increasing fertilizer rate; however, in U2-HP yield reached a maximum, and in $\mathrm{U} 2$ yield increased linearly (Fig. 3). The interpolated maximum yield in U2-HP was $50 \mathrm{~g} /$ plant at a rate supplying $261 \mathrm{mg} \mathrm{N} / \mathrm{L}$. In U2, the highest yield was $47 \pm 3.0 \mathrm{~g} /$ plant (mean \pm SEM) at the rate that supplied $283 \mathrm{mg} \mathrm{N} / \mathrm{L}$. At the highest fertilizer rate, yield was 2.1 times greater than at the lowest administered rate in U2-HP, and 2.2 times higher in $\mathrm{U} 2$. Pooled across fertilizer rates, yield was $11 \%$ higher in U2-HP than in U2 $(P=0.0013 ; n=$ 29 for U2-HP and $n=27$ for U2) with means $( \pm$ SEM) of $40 \pm 2.2 \mathrm{~g}$ and $36 \pm 2.0 \mathrm{~g}$, respectively. No interactive effect was detected between substrate and fertilizer rate on yield.

\section{Cannabinoids}

Fertilizer rate. Of the analyzed cannabinoids, only THC, THCA, CBG, and CBGA were above the detection limit $(0.05 \%)$. Also, CBG concentration data were not normally distributed and could not be fit into the model; therefore, only treatment means are presented for this data.

As fertilizer rate increased, there were varied responses in floral concentrations and cannabinoid yield per plant (Fig. 4). In U2, THC concentration had a quadratic response to increasing fertilizer rate with a minimum of $0.36 \%$ at a rate supplying $193 \mathrm{mg} \mathrm{N} / \mathrm{L}$. Averaged across fertilizer rates, THC concentration in U2-HP was $0.44 \% \pm 0.018 \%$ (mean \pm SEM) and in this substrate, there was no effect of fertilizer rate on THC concentration. In both substrates, THCA concentration decreased linearly with increasing fertilizer rate. THCA concentration from lowest to highest fertilizer rate was $21.6 \% \pm$ $0.64 \%$ to $16.7 \% \pm 0.51 \%$ for U2-HP and $21.0 \% \pm 0.63 \%$ to $18.1 \% \pm 0.85 \%$ for U2 (mean \pm SEM). In U2, CBGA concentration decreased linearly as fertilizer rate increased, ranging from $0.64 \% \pm 0.02 \%$ to $0.54 \% \pm$ $0.03 \%$ from lowest to highest fertilizer rate. In U2-HP, floral CBGA concentration averaged across fertilizer rates was $0.57 \% \pm$ $0.01 \%$ (mean \pm SEM) and in this substrate, there was no effect of fertilizer rate on CBGA concentration. Mean $\mathrm{CBG}$ concentration pooled across all treatments was $0.06 \% \pm$ $0.002 \%$ ( \pm SEM).

Fertilizer effects were more evident when analyzing cannabinoid yield (g/plant) as a function of fertilizer rate (Fig. 4, right). In U2-HP yield of floral THC responded quadratically to increasing fertilizer rate, reaching a maximum of $0.27 \mathrm{~g} / \mathrm{plant}$ at a rate supplying $223 \mathrm{mg} \mathrm{N} / \mathrm{L}$ and in U2, reaching minimum of $0.11 \mathrm{~g} / \mathrm{plant}$ at a rate supplying $103 \mathrm{mg} \mathrm{N} / \mathrm{L}$. Yield of floral THCA increased linearly in $\mathrm{U} 2$ and responded quadratically in U2-HP with a maximum of $9.4 \mathrm{~g} /$ plant at a rate supplying $212 \mathrm{mg} \mathrm{N} / \mathrm{L}$. For both substrates, yield of floral CBG increased linearly with increasing fertilizer rate. Finally, yield of floral CBGA responded quadratically to fertilizer rate in U2-HP with a maximum of $0.29 \mathrm{~g} /$ plant at a rate supplying $228 \mathrm{mg} \mathrm{N} / \mathrm{L}$ and increased linearly in U2.

To determine if increasing yield influenced cannabinoid concentrations, Pearson correlation coefficients were calculated to relate cannabinoid concentrations with floral dry weight. Pooled across treatments, floral THCA concentration decreased with increasing dry floral weight $(r=-0.44, P=0.0047)$, but there was no correlation between THC, $\mathrm{CBG}$, or CBGA concentration and dry floral weight.

Substrate type. In presenting the effects of substrate on cannabinoids, means were pooled across fertilizer rates; however, statistical analysis was based on the complete model. There were no differences in the floral concentration of THCA or CBGA between the two substrates; although, U2-HP had a THC concentration $20 \%$ higher than U2 $[0.53 \% \pm 0.016 \%$ and $0.44 \% \pm 0.025 \%$ (means \pm SEM), respectively; $F=16.9, P=$ $0.0008 ; n=20]$. There was also an interactive effect of substrate and fertilizer rate on THC concentration $(P=0.01852 ; n=4)$. At the lowest and highest fertilizer rates, THC concentrations did not differ between substrates; but, at all other rates, THC concentration was higher in U2-HP.

As with fertilizer rate, differences between substrates were more evident when comparing cannabinoid yield per plant. THC yield, THCA yield, and CBGA yield were all higher in U2-HP than in U2: THC yield by $57 \%(F=9.3, P \leq 0.0001 ; n=20)$, THCA yield by $22 \%(F=10.7, P \leq 0.0001 ; n=20)$, and CBGA yield by $20 \%(F=8.3, P \leq$ $0.0001 ; n=20)$. THC yield in U2-HP was $0.22 \pm 0.017 \mathrm{~g} /$ plant (means \pm SEM) and in U2 was $0.14 \pm 0.010 \mathrm{~g} /$ plant; THCA yield in U2$\mathrm{HP}$ was $7.9 \pm 0.47 \mathrm{~g} /$ plant and in U2 was $6.5 \pm$ $0.44 \mathrm{~g} /$ plant; and CBGA yield in U2-HP was $0.24 \pm 0.016 \mathrm{~g} /$ plant and in U2 was $0.20 \pm$ $0.013 \mathrm{~g} / \mathrm{plant}$. Substrate had no effect on CBG yield $[0.019 \pm 0.002 \mathrm{~g} /$ plant (mean \pm SEM) across all treatments].

Substrate EC, $p H$, and irrigation. In both substrates, EC increased linearly or responded quadratically over time at each fertilizer rate except at the lowest rate that supplied $57 \mathrm{mg} \mathrm{N} / \mathrm{L}$, in which EC decreased linearly (Fig. 5). At the final measurement before harvest (at week 6 of the flowering

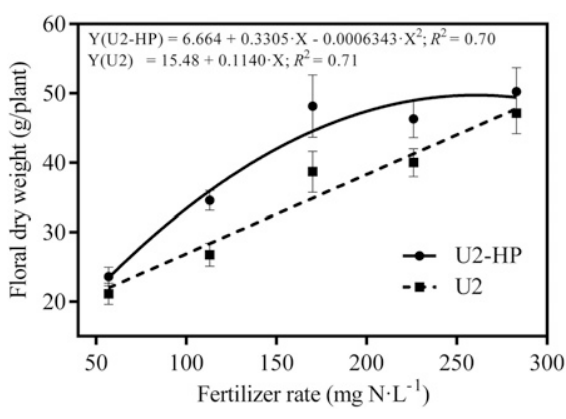

Fig. 3. Response of cannabis yield to organic fertilizer rate [indicated by nitrogen $(\mathrm{N})$ concentration] applied during the flowering stage in two growing substrates (U2-HP and U2). Values are means \pm SEM and the curves are best-fit regression relationship with $P<0.05$. For U2-HP, $n=5$ at the rate that supplied $170 \mathrm{mg} \mathrm{N} / \mathrm{L}$ and $n=6$ at each other fertilizer rate; for $\mathrm{U} 2, n=4$ at the rate that supplied $57 \mathrm{mg} \mathrm{N} / \mathrm{L}, n=5$ at the rate that supplied $113 \mathrm{mg} \mathrm{N} / \mathrm{L}$ and $n=6$ at each other rate.

stage), EC from the lowest to the highest fertilizer rate was $1.6 \pm 0.01$ to $6.0 \pm 0.31$ $\mathrm{mS} \cdot \mathrm{cm}^{-1}$ for U2-HP and $1.9 \pm 0.08$ to $6.3 \pm$ $0.35 \mathrm{mS} \cdot \mathrm{cm}^{-1}$ for $\mathrm{U} 2$ (means $\pm \mathrm{SEM}$ ). Averaged across fertilizer rates and time, EC was $6.3 \%$ higher in U2-HP than in $\mathrm{U} 2[3.1 \pm 97.2$ $\mathrm{mS} \cdot \mathrm{cm}^{-1}$ and $3.3 \pm 119.0 \mathrm{mS} \cdot \mathrm{cm}^{-1}$ (means \pm SEM), respectively; $F=4.8, P=0.03$ ].

Substrate $\mathrm{pH}$ decreased over time in all fertilizer rates and in both substrates $(\mathrm{Ta}-$ ble 3). Starting at 4 weeks in the flowering stage (WFS) until the end of the trial, $\mathrm{pH}$ was lower in U2-HP than in U2, differing by 0.4 0.9 during this time. There were no interactive effects of substrate and fertilizer rate on substrate EC or $\mathrm{pH}$.

To maintain a minimum substrate moisture content of $30 \%$, plants grown in U2-HP were fertigated 17 times during the flowering stage compared with 13 times for U2. Fertigation volume was $\approx 1 \mathrm{~L} /$ plant each time; therefore, during the flowering stage, plants grown in U2$\mathrm{HP}$ were given $31 \%$ more water ( $\approx 4 \mathrm{~L}$ more) and fertilizer than those grown in U2. For example, at the rate supplying $170 \mathrm{mg} \mathrm{N} / \mathrm{L}$, plants grown in U2-HP received $2.89 \mathrm{~g} \mathrm{~N} / \mathrm{L}$ of Nutri Plus Organic Bloom during the flowering stage compared with $2.21 \mathrm{~g} \mathrm{~N} / \mathrm{L}$ for U2.

\section{Discussion}

Both growing substrates, U2-HP and U2, performed well for cannabis production during the flowering stage; however, plants grown in U2-HP had higher GI, yield, THC concentration, THC yield, THCA yield, and CBGA yield than those grown in U2.

Yield increased with increasing fertilizer rate, reaching a plateau in U2-HP and until the highest applied rate for $\mathrm{U} 2$; however, as fertilizer rate increased, the concentration of most measured cannabinoids (THC, THCA, and CBGA) decreased. This suggests that for cannabis, high fertilizer rate during the flowering stage may have a dilution effect on THC, THCA, and CBGA. Although the dilution effect was apparent with increasing fertilizer rate, it did not have a substantial 

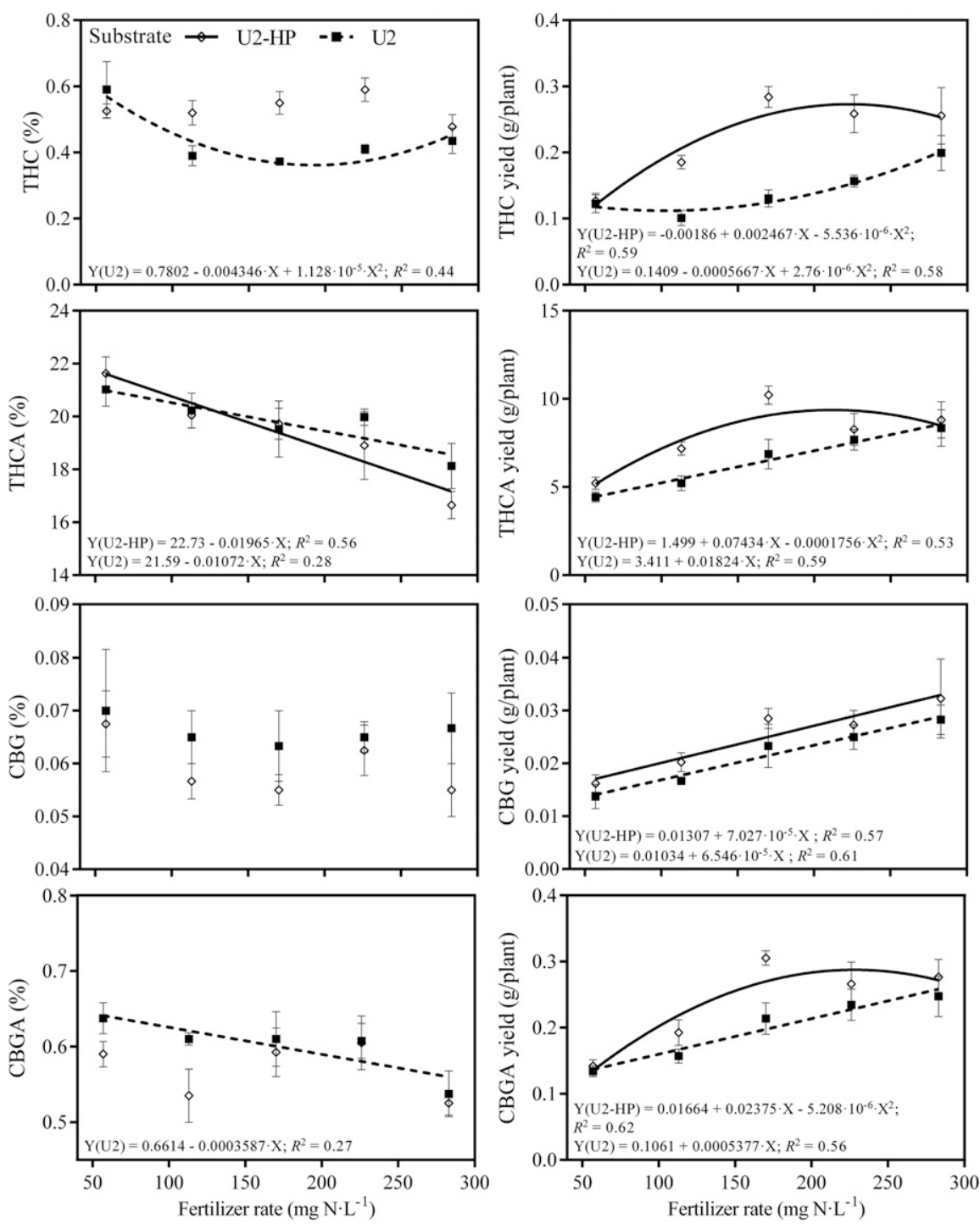

Fig. 4. Relationship between cannabinoid concentration in dry floral material (left) and cannabinoid yield per plant (right) and organic fertilizer rate applied during the flowering stage in two substrates (U2-HP and $\mathrm{U} 2)$. Fertilizer rate is indicated by nitrogen $(\mathrm{N})$ concentration. Values are means \pm SEM. The curve is the best fit regression relationship with $P<0.05$. In $\mathrm{U} 2-\mathrm{HP}$, for $\mathrm{CBG}$ concentration and yield at the rate that supplied $113 \mathrm{mg} \mathrm{N} / \mathrm{L}, n=3$ and at the rate that supplied $283 \mathrm{mg} \mathrm{N} / \mathrm{L}, n=2$. In U2, for CBG concentration and yield at the rates that supplied 57, 170, and $283 \mathrm{mg} \mathrm{N} / \mathrm{L}, n=3$ and at the rate that supplied $113 \mathrm{mg}$ $\mathrm{N} / \mathrm{L}, n=2$. For all other values, $n=4$. THC $=\Delta 9$-tetrahydrocannabinol; THCA $=\Delta 9$-tetrahydrocannabidiolic acid; $\mathrm{CBG}=$ cannabigerol; $\mathrm{CBGA}=$ cannabigerolic acid.

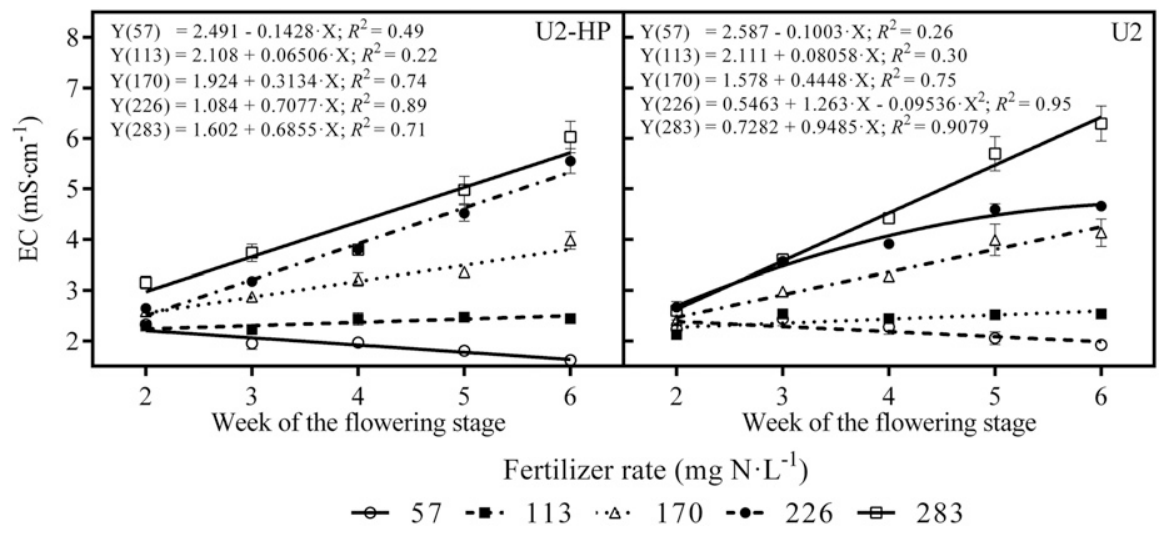

Fig. 5. Response of growing substrate electrical conductivity (EC) to organic fertilizer rate applied during the flowering stage for cannabis in two substrates (U2-HP and U2). Fertilizer rate is indicated by nitrogen (N) concentration. Data are means $\pm \operatorname{SEM}$ (For U2-HP, $n=4$ at weeks 2, 4, and 6 and $n=8$ at weeks 3 and 5; for $\mathrm{U} 2, n=4$ at each week) and lines are the best-fit regression relationships with $P<0.05$. impact on the total per-plant yield of most cannabinoids. This was evidenced by a lack of correlation between yield and THC, CBG, or CBGA concentrations. There was, however, a negative correlation between floral THCA concentration and yield, suggesting a slight dilution of THCA as yield increased. This illustrates that growing higher yielding cannabis plants is appropriate to maximize the yield of THC and CBGA with only minor losses of THCA. To maximize floral yield without sacrificing THC, THCA, and CBGA concentration due to the dilution effect, it is recommended that excessive organic fertilizer application during the flowering stage be avoided.

In U2-HP, peak yield, THC yield, THCA yield, and CBGA yield were at rates supplying 261, 223, 212, and $228 \mathrm{mg} \mathrm{N} / \mathrm{L}$, respectively. Therefore, for U2-HP, the optimal rate of this organic fertilizer is between 212 and $261 \mathrm{mg} \mathrm{N} / \mathrm{L}$, depending on grower preference for high yield or individual cannabinoid yield. For U2, yield did not reach a plateau over the applied fertilizer rates; therefore, growers may choose to maximize yield using the highest fertilizer rate that supplied $283 \mathrm{mg} \mathrm{N} / \mathrm{L}$ or chose a lower rate to maximize cannabinoid concentration. Growing substrate U2-HP is preferential to achieve maximum yield and cannabinoid content, whereas U2 has the potential to reduce water and fertilizer use if the nutrient solution is not reused.

Some of the differences between the two substrates may have been accounted for by differences in irrigation frequency. Because irrigation frequency was based on substrate moisture content, the drier substrate (U2-HP) was irrigated, and consequently fertilized, more frequently than $\mathrm{U} 2$. The differences in performance between the two substrates were greater than that could be accounted for by the additional fertilizer applied in U2-HP over the duration of flowering stage. For example, yield was higher in U2-HP at the rate that supplied $170 \mathrm{mg} \mathrm{N} / \mathrm{L}$ than yield in $\mathrm{U} 2$ at the rate that supplied $226 \mathrm{mg} \mathrm{N} / \mathrm{L}$, whereas the total fertilizer applied was 2.89 and $2.94 \mathrm{~g} \mathrm{~N} / \mathrm{L}$, respectively. High irrigation frequency is known to increase plant growth in some species (de Kreij and Straver, 1988; Katsoulas et al., 2006; Morvant et al., 1998; Silber et al., 2003, 2005). In greenhousegrown roses (Rosa hybrid L., 'First Red'), doubling irrigation frequency while maintaining constant total irrigation volume increased the dry weight of cut flower shoots by $\approx 30 \%$ over a lower frequency irrigation (Katsoulas et al., 2006). Similar effects have been reported in greenhouse-grown Codiaeum variegatum L.; using a flood and drain irrigation system, de Kreij and Straver (1988) found that high irrigation frequency combined with high-porosity substrates increased plant growth and reduced substrate nutrient leaching. Increased irrigation frequency can also increase aboveground biomass in lettuce (Lactuca sativa L., 'Iceberg'; Silber et al., 2003) and peppers (C. annum L., 'Selika'; Silber et al., 2005). The increased 
Table 3. Response of substrate $\mathrm{pH}$ to organic fertilizer rate applied during the flowering stage for cannabis.

\begin{tabular}{|c|c|c|c|c|c|c|c|c|c|c|c|c|c|}
\hline & \multicolumn{12}{|c|}{ Growing substrate } & \multirow[b]{5}{*}{ Substrate $^{\mathrm{x}}$} \\
\hline & \multicolumn{6}{|c|}{$\mathrm{U} 2-\mathrm{HP}$} & \multicolumn{6}{|c|}{$\mathrm{U} 2$} & \\
\hline \multirow[b]{3}{*}{$\mathrm{WFS}^{\mathrm{y}}$} & \multicolumn{12}{|c|}{ Fertilizer rate [indicated by nitrogen $\left(\mathrm{mg} \cdot \mathrm{L}^{-1} \mathrm{~N}\right)$ concn] } & \\
\hline & 57 & 113 & 170 & 226 & 283 & $\mathrm{All}^{\mathrm{z}}$ & 57 & 113 & 170 & 226 & 283 & $\mathrm{All}^{\mathrm{z}}$ & \\
\hline & \multicolumn{12}{|c|}{ Growing substrate $\mathrm{pH}$} & \\
\hline 2 & $7.4 \mathrm{a}^{\mathrm{w}}$ & $7.2 \mathrm{a}$ & $7.3 \mathrm{a}$ & $7.2 \mathrm{a}$ & $7.2 \mathrm{a}$ & $7.3 \pm 0.04$ & $7.4 \mathrm{a}$ & $7.3 \mathrm{a}$ & $7.1 \mathrm{a}$ & $7.6 \mathrm{a}$ & $6.9 \mathrm{a}$ & $7.2 \pm 0.09$ & NS \\
\hline 3 & $7.0 \mathrm{a}$ & $6.7 \mathrm{ab}$ & $6.4 \mathrm{~b}$ & $6.7 \mathrm{ab}$ & $6.5 \mathrm{ab}$ & $6.7 \pm 0.06$ & $7.0 \mathrm{a}$ & $6.4 \mathrm{a}$ & $6.6 \mathrm{a}$ & $6.4 \mathrm{a}$ & $6.3 \mathrm{a}$ & $6.6 \pm 0.09$ & NS \\
\hline 4 & $6.0 \mathrm{a}$ & $6.0 \mathrm{a}$ & $5.7 \mathrm{a}$ & $6.0 \mathrm{a}$ & $5.9 \mathrm{a}$ & $5.9 \pm 0.10$ & $6.6 \mathrm{a}$ & $6.2 \mathrm{a}$ & $6.3 \mathrm{a}$ & $6.3 \mathrm{a}$ & $6.0 \mathrm{a}$ & $6.3 \pm 0.09$ & $* *$ \\
\hline 5 & $5.9 \mathrm{a}$ & $5.6 \mathrm{a}$ & $5.6 \mathrm{a}$ & $5.9 \mathrm{a}$ & $5.8 \mathrm{a}$ & $5.8 \pm 0.08$ & $6.9 \mathrm{a}$ & $6.4 \mathrm{a}$ & $6.1 \mathrm{a}$ & $6.4 \mathrm{a}$ & $6.4 \mathrm{a}$ & $6.5 \pm 0.09$ & $* * *$ \\
\hline 6 & $6.0 \mathrm{a}$ & $5.5 \mathrm{ab}$ & $5.5 \mathrm{ab}$ & $5.8 \mathrm{ab}$ & $5.1 \mathrm{~b}$ & $5.6 \pm 0.10$ & $6.9 \mathrm{a}$ & $6.4 \mathrm{a}$ & $6.5 \mathrm{a}$ & $6.5 \mathrm{a}$ & $6.4 \mathrm{a}$ & $6.5 \pm 0.07$ & $* * *$ \\
\hline $\mathrm{All}^{\mathrm{v}}$ & $6.5 \pm 0.13$ & $6.2 \pm 0.14$ & $6.1 \pm 0.15$ & $6.3 \pm 0.13$ & $6.1 \pm 0.14$ & $6.2 \pm 0.06$ & $7.0 \pm 0.08$ & $6.5 \pm 0.12$ & $6.5 \pm 0.10$ & $6.6 \pm 0.12$ & $6.4 \pm 0.09$ & $6.6 \pm 0.05$ & \\
\hline
\end{tabular}

${ }_{\mathrm{z}}$ Data are means of substrates pooled across fertilizer rates.

${ }^{\mathrm{y}} \mathrm{WFS}=$ weeks in the flowering stage.

${ }^{\mathrm{x}} \mathrm{NS},{ }^{*}{ }^{* *},{ }^{* * *}$ Nonsignificant, or significant at $P<0.05,0.01$, and 0.0001 , respectively, within week intervals among substrate treatments

${ }^{\mathrm{w}}$ Data followed by the same letter within the same column do not differ at $P<0.05$.

${ }^{\mathrm{v}}$ Data are means of 6 weeks; for U2-HP, $n=4$ at 2, 4 and 6 WFS and $n=8$ at 3 and 5 WFS; for U2, $n=4$ at each WFS.

growth from frequent irrigation has been attributed to enhanced nutrient uptake, specifically improved $\mathrm{P}$ mobilization and uptake (Silber et al., 2003, 2005).

Another factor that may have contributed to the differences in growth and cannabinoid concentrations/yield between the two substrates is root zone oxygen availability. With a higher CC (Table 1), U2 holds more water, consequentially displacing more air and reducing the oxygen diffusing rate in the root zone compared to U2-HP. A welloxygenated root zone is vital for good plant health, improving nutrient uptake, root growth and preventing root-borne disease (Jackson and Colmer, 2005; Zheng et al., 2007). Furthermore, there was some evidence of root disease in the present study that may have been caused by low root zone oxygen. While there was no statistical difference, three plants were removed during the trial due to root rot in U2 compared with one in U2-HP. To our knowledge, there is no research into the effects of irrigation or root zone oxygen on cannabinoid concentrations, but it is speculated that these factors may have contributed to the higher cannabinoid concentrations seen in U2-HP. Results from the present study suggests that cannabis may benefit from high irrigation frequency and/or high root zone oxygen; however, further study is required to control for these variables and to optimize irrigation frequency and root zone oxygen concentration for cannabis.

Plant growth responded as expected to varying fertilizer application rates; plants increased in size as fertilizer rate increased until a maximum at a rate supplying $211 \mathrm{mg}$ $\mathrm{N} / \mathrm{L}$ for $\mathrm{U} 2-\mathrm{HP}$ and at a rate supplying $239 \mathrm{mg} \mathrm{N} / \mathrm{L}$ for $\mathrm{U} 2$ at final harvest. The fertilizer rates which delivered optimal growth and yield in this trial were generally higher than typical recommended synthetic fertilizer rates used in container crop production, which rarely exceed $200 \mathrm{mg} \mathrm{N} / \mathrm{L}$ (Raviv and Lieth, 2007); this was likely due to the slow releasing and less soluble nature of $\mathrm{N}$ and $\mathrm{P}$ in organic fertilizer when compared with most synthetic fertilizers (Prasad et al., 2004). Improved performance from high organic fertilizer rates (at rates supplying around $389 \mathrm{mg} \mathrm{N} / \mathrm{L}$ ) was also reported for vegetative stage cannabis (Caplan et al., 2017), suggesting that cannabis has high organic fertilizer requirements in both growth stages.

Caplan et al. (2017) also demonstrated that with varying fertilizer rate and substrate type applied to vegetative-stage cannabis, that cannabinoid yield and concentration did not differ substantially in the variety 'OG Kush $\times$ Grizzly' when the plants were grown under similar flowering-stage conditions. During the vegetative stage, substrate had no effect on floral cannabinoid concentration, and of all the detected cannabinoids only THC concentration responded to fertilizer rate, increasing to a maximum at a rate supplying $418 \mathrm{mg}$ N/L. Fertilizer effects were more substantial in the present study, likely because cannabinoid concentration increases mainly during the flowering stage when glandular trichome development is at its peak (Aizpurua-Olaizola et al., 2016; Muntendam et al., 2012). In addition, Caplan et al. (2017) found that an increase in yield due to optimal vegetative-stage fertigation was associated with an increase in the concentration of THC and cannabinol (CBN) in dry floral material. In the present study, there was negligible $\mathrm{CBN}$ detected in the floral material of the variety 'WP:Med (Wappa)', and results differ from Caplan et al. (2017) with regards to THC concentration. The cannabinoid dilution effect, attributed to increased fertilizer rate, may therefore only apply to the flowering stage. This difference illustrates a varying effect between vegetative stage and flowering stage fertilizer rate for cannabis.

The relationship between fertilizer rate and yield differed between the two substrates. In U2-HP, yield decreased at rates that supplied above $261 \mathrm{mg} \mathrm{N} / \mathrm{L}$, yet yield increased linearly with increasing fertilizer rate in U2. The concentration of fertilizer in the irrigation water remained constant; therefore, more fertilizer was used for U2-HP than U2 over the 53-d period. It was presumed that since more fertilizer was administered for U2-HP, that substrate EC would accumulate to a higher level in U2-HP compared with U2. In fact, the opposite was observed; substrate
EC was slightly higher in U2 than in U2-HP (Fig. 5). Plants grown in U2-HP also grew larger, potentially because of increased irrigation frequency and/or substrate aeration as previously described. Increased plant growth may have facilitated greater nutrient uptake, accounting for lower EC accumulation in U2HP. Silber et al. (2003) found that in lettuce, increased irrigation frequency improved the availability of immobile elements such as $\mathrm{P}$ and $\mathrm{K}$ allowing for increased uptake. In U2$\mathrm{HP}$, at rates that supplied above $261 \mathrm{mg} \mathrm{N} / \mathrm{L}$, plants may have accumulated nutrients to above-optimum levels, which could account for the yield reduction at the higher rates. By contrast, the lesser amount of total administered fertilizer in U2 might have not reached an optimum level.

Low substrate $\mathrm{pH}$ may have also contributed to the yield reductions seen at the highest fertilizer rate in U2-HP. The optimal $\mathrm{pH}$ range for cannabis that is suggested by grey resources (Cervantes, 2006) and found to be acceptable in our previous trial during the vegetative stage (Caplan et al., 2017 ) is $5.8-7.2$. The $\mathrm{pH}$ in both substrates remained mostly within this range; however, at the highest fertilizer rate at 6 WFS, $\mathrm{pH}$ in U2-HP was 5.1. Within the measured range of substrate $\mathrm{pH}$ (means of 5.1-7.4 in the flowering stage) there were no visual signs of $\mathrm{pH}$-induced disorders. This observation overlaps the acceptable range cited in Caplan et al. (2017) of 6.7-7.2 for the flowering stage. If the lowest substrate $\mathrm{pH}$ measured (5.1) is excluded, a range of substrate $\mathrm{pH}$ of 5.5-7.4 appears suitable in the flowering stage for container production of organic cannabis. More research is needed to confirm the optimal range for multiple varieties.

Leaf 'greenness' increased linearly with increasing fertilizer rate and was positively correlated to the proceeding GI measurement as well as yield. The CCI is often a reliable indicator of leaf N-status; however, the relationship must be determined for a given species using leaf tissue analysis for accurate results (Xiong et al., 2015), and to our knowledge has not been characterized for cannabis. Current results suggest that $\mathrm{CCI}$ may be an indicator of plant $\mathrm{N}$-status for 
cannabis since yield and growth generally increase with optimal $\mathrm{N}$ fertilization.

Finally, further research is required to evaluate the effects of fertilizer rate and substrate on other cannabinoids of interest, such as $\mathrm{CBD}$, which was not detected in the current variety 'WP:Med (Wappa)'. This would require the use of additional cannabis varieties.

\section{Conclusions}

Our results suggest that to produce highyielding, cannabinoid-rich, organic cannabis plants, lower CC coir-based substrates, such as U2-HP, are preferable to those with higher $\mathrm{CC}$, such as U2. The drier substrate produced higher floral yield, GI, THC concentration, THC yield, THCA yield, and CBGA yield than U2, possibly because of higher fertigation frequency or adequate root zone oxygen leading to a more favorable root zone environment. Both substrates generally maintained suitable substrate $\mathrm{pH}$ between 5.5 and 7.4 and were effective for cannabis production during the flowering stage. Increasing fertilizer rate was found to have a dilution effect on THC, THCA, and CBGA; therefore, excessive organic fertilizer application during the flowering stage should be avoided despite increased biomass yield. To maximize both yield and cannabinoid yield, the optimal organic fertilizer rate for U2-HP was determined to be within a range supplying 212-261 mg N/L using the Nutri Plus Organic Bloom liquid organic fertilizer during the flowering growth stage. Higher rates within this range favor increased floral yield, whereas lower rates favor higher yield of some cannabinoids. For U2, the optimal rate was one supplying $283 \mathrm{mg} \mathrm{N} / \mathrm{L}$ to maximize yield; although, lower rates may be desirable to increase cannabinoid concentrations. These recommendations could be generalized for similar organic fertilizer and substrates; however, results may vary with cannabis variety.

\section{Literature Cited}

Ahmed, S.A., S.A. Ross, D. Slade, M.M. Radwan, I.A. Khan, and M.A. ElSohly. 2015. Minor oxygenated cannabinoids from high potency Cannabis sativa L. Phytochemistry 117:194199.

Ahmed, S.A., S.A. Ross, D. Slade, M.M. Radwan, F. Zulfiqar, and M.A. ElSohly. 2008. Cannabinoid ester constituents from high potency Cannabis sativa L. Planta Med. 74:536 542.

Aizpurua-Olaizola, O., U. Soydaner, E. Öztürk, D. Schibano, Y. Simsir, P. Navarro, N. Etxebarria, and A. Usobiaga. 2016. Evolution of the cannabinoid and terpene content during the growth of Cannabis sativa plants from different chemotypes. J. Nat. Prod. 79:324-331.

Amaducci, S., D. Scordia, F.H. Liu, Q. Zhang, H. Guo, G. Testa, and S.L. Cosentino. 2015. Key cultivation techniques for hemp in Europe and China. Ind. Crops Prod. 68:2-16.

ArcView Market Research. 2017. The state of legal marijuana markets. 5th ed. ArcView Mkt. Res., San Francisco, CA.
Aubin, M-P., P. Seguin, A. Vanasse, G.F. Tremblay, A.F. Mustafa, and J-B. Charron. 2015. Industrial hemp response to nitrogen, phosphorus, and potassium fertilization. Crop. Forage Turfgrass Mgt. 1:1-10.

Bar-Yosef, B. 1999. Advances in fertigation. Adv. Agron. 65:1-77.

Baxter, W.J. and G. Scheifele. 2008. Growing industrial hemp in Ontario. Ontario Ministry of Agriculture, Food and Rural Affairs. Queen's Printer for Ontario, Toronto, Canada.

Bowley, S. 1999. A hitchhiker's guide to statistics in plant biology. Any Old Subject Books, Guelph, Canada.

Caplan, D., M. Dixon, and Y. Zheng. 2017. Optimal rate of organic fertilizer during the vegetative-stage for cannabis grown in two coir-based substrates. HortScience 52:13071312.

Cervantes, J. 2006. Marijuana horticulture: The indoor/outdoor medical grower's bible. Van Patten Publishing, Vancouver, WA.

de Kreij, C. and N. Straver. 1988. Flooded-bench irrigation: Effect of irrigation frequency and type of potting soil on growth of Codiaeum and on nutrient accumulation in the soil. Acta Hort. 221:245-252.

Ehrensing, D.T. 1998. Feasibility of industrial hemp production in the United States Pacific Northwest. Oregan State Univ. Agr. Expt. Sta. Bul. 681.

ElSohly, M.A. and D. Slade. 2005. Chemical constituents of marijuana: The complex mixture of natural cannabinoids. Life Sci. 78:539548.

Elzinga, S., J. Fischedick, R. Podkolinski, and J.C. Raber. 2015. Cannabinoids and terpenes as chemotaxonomic markers in cannabis. Nat. Prod. Chem. Res. 3:1-9.

Farag, S. and O. Kayser. 2015. Cultivation and breeding of Cannabis sativa L. for preparation of standardized extracts for medicinal purposes. Medicinal and aromatic plants of the world. Springer, Dordrecht, The Netherlands.

Hillig, K.W. and P.G. Mahlberg. 2004. A chemotaxonomic analysis of cannabinoid variation in cannabis (Cannabaceae). Amer. J. Bot. 91:966-975.

Jackson, M.B. and T.D. Colmer. 2005. Response and adaptation by plants to flooding stress. Ann. Bot. 96:501-505.

Katsoulas, N., C. Kittas, G. Dimokas, and C. Lykas. 2006. Effect of irrigation frequency on rose flower production and quality. Biosyst. Eng. 93:237-244.

Kimura, M. and K. Okamoto. 1970. Distribution of tetrahydrocannabinolic acid in fresh wild cannabis. Experientia 26:819-820.

Knight, G., S. Hansen, M. Connor, H. Poulsen, C. McGovern, and J. Stacey. 2010. The results of an experimental indoor hydroponic cannabis growing study, using the "Screen of Green" (ScrOG) method-yield, tetrahydrocannabinol (THC) and DNA analysis. Forensic Sci. Intl. 202:36-44.

Leggett, T. 2006. Review of the world cannabis situation. Bul. Narc. 58:1-155.

Mechoulam, R., A. Shani, H. Edery, and Y. Grunfeld. 1970. Chemical basis of hashish activity. Science 169:611-612.

Morvant, J.K., J.M. Dole, and J.C. Cole. 1998. Irrigation frequency and system affect poinsettia growth, water use, and runoff. HortScience 33:42-46.

Muntendam, R., N. Happyana, T. Erkelens, F. Bruining, and O. Kayser. 2012. Time dependent metabolomics and transcriptional analysis of cannabinoid biosynthesis in Cannabis sativa var. Bedrobinol and Bediol grown under standardized condition and with genetic homogeneity. Online Intl. J. Med. Plants Res. 1:31-40.

Potter, D.J. 2014. A review of the cultivation and processing of cannabis (Cannabis sativa $\mathrm{L}$.) for production of prescription medicines in the UK. Drug Test. Anal. 6:31-38.

Potter, D.J. and P. Duncombe. 2012. The effect of electrical lighting power and irradiance on indoor-grown cannabis potency and yield. J. Forensic Sci. 57:618-622.

Prasad, M., P. Simmons, and M.J. Maher. 2004. Release characteristics of organic fertilizers. Acta Hort. 644:163-170.

Radwan, M.M., M.A. ElSohly, A.T. El-Alfy, S.A. Ahmed, D. Slade, A.S. Husni, S.P. Manly, L. Wilson, S. Seale, S.J. Cutler, and S.A. Ross. 2015. Isolation and pharmacological evaluation of minor cannabinoids from highpotency Cannabis sativa. J. Nat. Prod. 78: $1271-1276$

Raviv, M. and J.H. Lieth. 2007. Soilless culture: Theory and practice. 1st ed. Elsevier B.V., Burlington, MA.

Ross, S.A. and M.A. ElSohly. 1997. CBN and 49 THC concentration ratio as an indicator of the age of stored marijuana samples. Bul. Narc. 49:139.

Russo, E.B. 2007. History of cannabis and its preparations in saga, science, and sobriquet. Chem. Biodivers. 4:1614-1648.

Ruter, J.M. 1992. Influence of source, rate, and method of applicating controlled release fertilizer on nutrient release and growth of "Savannah" holly. Fert. Res. 32:101-106.

Silber, A., M. Bruner, E. Kenig, G. Reshef, H. Zohar, I. Posalski, H. Yehezkel, D. Shmuel, S. Cohen, M. Dinar, E. Matan, I. Dinkin, Y. Cohen, L. Karni, B. Aloni, and S. Assouline. 2005. High fertigation frequency and phosphorus level: Effects on summer-grown bell pepper growth and blossom-end rot incidence. Plant Soil 270:135-146.

Silber, A., G. Xu, and R. Wallach. 2003. High irrigation frequency: The effect on plant growth and on uptake of water and nutrients. Acta Hort. 627:89-96.

Surrage, V.A., C. Lafrenière, M. Dixon, and Y. Zheng. 2010. Benefits of vermicompost as a constituent of growing substrates used in the production of organic greenhouse tomatoes. HortScience 45:1510-1515.

Taschwer, M. and M.G. Schmid. 2015. Determination of the relative percentage distribution of THCA and $\Delta(9)$-THC in herbal cannabis seized in Austria-Impact of different storage temperatures on stability. Forensic Sci. Intl. 254:167-171.

United Nations Office on Drugs and Crime. 2009. Recommended methods for the identification and analysis of cannabis and cannabis products, manual for use by national drug analysis laboratories. Laboratory and Scientific Section, United Nations Office on Drugs and Crime, Vienna, Austria.

van Bakel, H., J.M. Stout, A.G. Cote, C.M. Tallon, A.G. Sharpe, T.R. Hughes, and J.E. Page. 2011. The draft genome and transcriptome of Cannabis sativa. Genome Biol. 12:1-17.

Vanhove, W., T. Surmont, P. Van Damme, and B. De Ruyver. 2012. Yield and turnover of illicit indoor cannabis (Cannabis spp.) plantations in Belgium. Forensic Sci. Intl. 220:265-270.

Vanhove, W., P. Van Damme, and N. Meert. 2011. Factors determining yield and quality of illicit indoor cannabis (Cannabis spp.) production. Forensic Sci. Intl. 212:158-163. 
Vemuri, V.K. and A. Makriyannis. 2015. Medicinal chemistry of cannabinoids. Clin. Pharmacol. Ther. 97:553-558.

Vera, C.L., S.S. Malhi, J.P. Raney, and Z.H. Wang. 2004. The effect of $\mathrm{N}$ and $\mathrm{P}$ fertilization on growth, seed yield and quality of industrial hemp in the Parkland region of Saskatchewan. Can. J. Plant Sci. 84:939-947.

Vollner, L., D. Bieniek, and F. Korte. 1986. Review of analytical methods for identification and quantification of cannabis products. Regulat. Toxicol. Pharmacol. 6:348-358.

Warncke, D.D. 1986. Analyzing greenhouse growth media by the saturation extraction method. HortScience 21:223-225.
Wright, R.D. 1986. The pour-through nutrient extraction procedure. HortScience 21:227-229.

Wright, R.D. and A.X. Niemiera. 1987. Nutrition of container-grown woody nursery crops. Hort. Rev. 9:75-101.

Xiong, D., J. Chen, T. Yu, W. Gao, X. Ling, Y. Li, S. Peng, and J. Huang. 2015. SPAD-based leaf nitrogen estimation is impacted by environmental factors and crop leaf characteristics. Sci. Rpt. 5:13389.

$\mathrm{Xu}$, G., S. Wolf, and U. Kafkafi. 2001. Effect of varying nitrogen form and concentration during growing season on sweet pepper flowering and fruit yield. J. Plant Nutr. 24:1099-1116.
Zhai, Z., D.L. Ehret, T. Forge, T. Helmer, W. Lin, and A.P. Papadopoulos. 2009. Organic fertilizers for greenhouse tomatoes: Productivity and substrate microbiology. HortScience 44:800-809.

Zheng, Y. 2016. Root zone environment management in container crop production. Proc. for the Veg., Potato, Greenhouse, Small Fruit \& Gen. Session Mid-Atlantic Fruit \& Veg. Convention, Hershey, PA.

Zheng, Y., L. Wang, and M. Dixon. 2007. An upper limit for elevated root zone dissolved oxygen concentration for tomato. Sci. Hort. 113:162-165. 